\title{
Importance of Extrinsic Quality Assessment Criteria when South African Female Consumers Evaluate Casual Daywear
}

\section{Susanna Hendrina Hugo}

Dept. Visual Arts and Design, Vaal University of Technology, Vanderbijlpark, South Africa

\author{
Prof. Annette Marié van Aardt
}

School of Business Management, North-West University

Potchefstroom, South Africa

Doi:10.5901/mjss.2014.v5n20p2133

\begin{abstract}
To gain competitive advantage, marketers must make sure that they meet consumers' needs and demands, to guarantee their satisfaction. It is therefore crucial that marketers will know to what extent their apparel customers apply evaluative criteria to assess clothing quality. The aim of this study was to determine the importance of extrinsic evaluative criteria used by female fashion consumers in the Vaal Region to assess apparel quality when purchasing casual daywear. For this quantitative study a self-administered, structured, validated questionnaire was developed to test how important the female lecturers at the Vaal University of Technology (in the North-West Province in South Africa) deemed six extrinsic evaluative criteria when purchasing casual daywear. Mean scores showed that appropriateness of the garments for a specific purpose was rated most important, followed by price and labels. Store image was rated in the fourth place, while brand and country of origin were rated much lower than all the other attributes. It was concluded that apparel manufacturers and retailers should take note of the outcomes of this study in order to understand consumers' selection criteria when purchasing apparel. In-depth information on apparel consumer preferences could help retailers to plan their merchandise mix more efficiently, to identify niche markets and to develop targeting strategies for the various markets. Retailers could, in co-operation with consumer educational authorities, develop educational opportunities during which consumers could be made aware of the importance of using a wide variety of applicable evaluative criteria in order to make informed and responsible apparel purchase decisions.
\end{abstract}

Keywords: Female apparel, quality, assessment, extrinsic criteria, casual daywear

\section{Introduction}

Promising superior value and delivering customer satisfaction is the essence of successful marketing. Meeting consumers' needs and demands is a prerequisite for their satisfaction (Kotler \& Armstrong, 2010:28,30). Criteria used by fashion consumers to assess quality and acceptability of apparel products during the decision-making process is a good indication of considerations which retailers and manufacturers must keep in mind to ensure customer satisfaction. Evaluative criteria are manifestations of consumers' values, attitudes and experience, as well as psychological, social and economic influences (Eckman, Damhorst \& Kadolph, 1990:13).

When consumers assess apparel quality, they use two main categories of criteria, namely intrinsic and extrinsic (Abraham-Murali \& Littrell, 1995a:150; Brown \& Rice, 2001:47-48; Retief \& De Klerk, 2003:25). Part I of the present study focused on intrinsic criteria (Hugo \& Van Aardt, 2012:460-471) while part II (this article) centres around extrinsic criteria. Physical apparel attributes such as price, brand, hangtag/label, country of origin, and store image as well as appropriateness for casual wear (an applicable criterion for this study) are classified as extrinsic criteria.

\section{Problem Statement}

Various studies have attempted to identify criteria which apparel consumers apply to assess the quality of clothing (Eckman et al., 1990:13; Forsythe, Presley \& Caton, 1996:299; Retief \& De Klerk, 2003:24-25). World-wide, consumers are becoming concerned about what to look for in terms of quality of textile products, and the industry and the customer do not always have the same opinion about ways in which quality of apparel products should be assessed (Kadolph, 1998:12) 


\section{Research Question}

The research question for this study was formulated as follows: How important are the various extrinsic apparel attributes to female consumers when they evaluate the quality of apparel suitable for casual daywear?

\section{Aims of the Study}

The broad research aim of this exploratory study was to determine to what extent extrinsic evaluative criteria are used by female fashion consumers in the Vaal Region to assess apparel quality when purchasing casual daywear, in order to make recommendations regarding consumer education as well as retail strategies.

Specific objectives were to determine how important selected extrinsic evaluative criteria namely price, brand, store image, labels, country of origin and appropriateness for the purpose (in this case, casual daywear) are when assessing the quality of casual daywear, as well as to determine whether distinct clusters of fashion consumers can be identified, based on the criteria applied when judging apparel quality.

\section{Conceptual Framework}

The conceptual framework (Figure 1) developed for this study reflects the theoretical approach and was based on models used for assessment of the quality of clothing products by Eckman et al. (1990:17), Brown and Rice (2001:47-53), Zhang, Li, Gong, and Wu (2002:55) and Retief and De Klerk (2003:25).

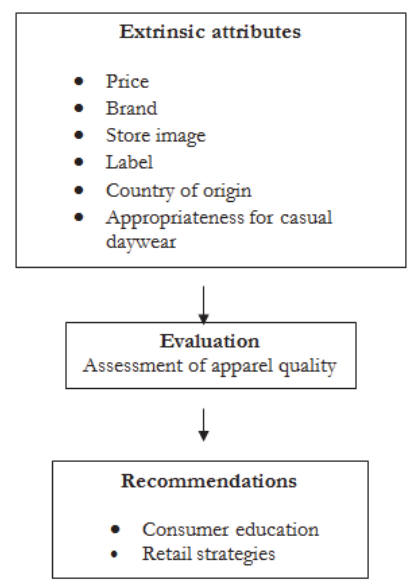

Figure 1: Conceptual framework.

\section{Literature Review}

Consumers' perception of the garments which they consider purchasing, embraces garment analysis and the application of specific evaluative criteria in order to assess garment quality. Kadolph $(1998: 4,13-14)$ points out that quality is a multidimensional concept which cannot be addressed by a single definition in terms of all the dimensions, areas of impact, and concerns related to quality. For the purpose of this study quality can be defined as the ability of a product to meet consumers' needs and satisfy their demands, or as the total set of attributes that contribute to consumer's expectations (Hawkins, Mothersbaugh \& Best, 2007:192)

\subsection{Apparel quality}

Garment quality implies a wide range of characteristics which may indicate superiority, excellence, or a perceived level of value. When considering perspectives on quality assessment, the viewpoint of the consumer as well as the viewpoint of the manufacturer is relevant (Abraham-Murali, 1995a:149, Hines \& O'Neal, 1995:227). Quality concerns of manufacturers 
and merchandisers focus mainly on how to meet the consumer's needs and expectations of quality, which implies that the merchandiser has to analyse and understand the quality demands of the consumer that determine consumer satisfaction (Rosenau \& Wilson, 2006:296). According to Solomon and Rabolt (2009:479) consumers look for both quality and value. They point out that claims of product quality have become critical in maintaining a competitive advantage by retailers.

\subsection{Extrinsic attributes}

Extrinsic attributes are those textile product characteristics that are not constituent parts of the fashion product, but that are allocated to the product by the manufacturer or retailer, such as price and brand, which are two of the most frequently used extrinsic attributes used by apparel consumers to assess clothing quality (North, De Vos and Kotzé, 2003:42).

In order to increase the depth of the investigation of the influence of extrinsic attributes on the appraisal of apparel quality, the social cognitive theory can be applied to the evaluation process. Consumers' experience with reference to any of these attributes associated with apparel quality results in mental frameworks, known as schemas, for understanding such situations (Baron \& Byrne, 2000:81; Erasmus, Boshoff \& Rousseau, 2002:3). These schemas focus on a specific topic and assist individuals in organizing social information, such as linking price or a brand name to the quality of garments. Schemas tend to remain unchanged even when conflicting information is come across, and consumers may use mental shortcuts or heuristics (Baron \& Byrne, 2000:86), for instance when information overload is experienced, to reduce mental effort and make conclusions in a rapid, apparently effortless way, for example when linking high prices or a well-known brand name to good quality when assessing apparel value.

\subsubsection{Price}

Schiffman and Kanuk (2007:177) point out that reference prices are often used by consumers as a basis for comparison in judging prices. Reference prices can be determined externally, as when a product is advertised as cheaper than it is everywhere else. External reference prices are understood by most consumers and they are influenced by these prices, but do not always believe them, because some retailers may have originally set prices that were too high and are then compelled to lower the prices due to low sales (Hawkins et al., 2007:613). Individuals who gain more knowledge about a subject, such as the price of a product they intend to buy, can add this information to the network or schema and later retrieve this information for reference purposes, or apply heuristics to make decisions.

Authors such as Hoyer and Mclnnes (2007:218) and Schiffman and Kanuk $(2007: 183,188)$ agree that it is necessary to take into account that consumers often view price as a signal of and substitute for quality, implying that a high price supports marketers' claims of quality. Hawkins et al. (2007:759) warn that retail managers must follow a pricing policy that is compatible with the desired product position. External, internal and situational influences must be considered, such as whether it is necessary to lower the price in order to obtain a competitive advantage, whether price will be perceived as an indicator of status, whether price plays a significant role in the market segment's attitude towards the brands in the product category and, especially, whether price is an important evaluative criterion.

\subsubsection{Brand}

Brand image can be defined as the schematic image of a brand, which represents the target market's understanding of the product's attributes, advantages, consumption situation, users' and manufacturer/marketer characteristics. Hawkins et al. (2007:346) argue that brands reflect what people experience when they hear or see a brand name and is a combination of associations that consumers have learned about the brand. They claim that brands take on parts that extend well beyond the intrinsic attributes of the product and convey messages such as "I am just like you".

Baron and Byrne (2000:86) point out that consumers don't necessarily follow the whole decision-making process each time. Upon perceiving a brand name, people often use a cognitive short-cut (heuristic) based on existing schemata, which requires less cognitive effort to make a buying decision. Hoyer and McInnes (2007:202-203) support this likelihood by contending that brand names are often recalled during internal searches for information in order to make purchase decisions

There is plenty of evidence in the literature to suggest that brand names are used to judge quality and value of products (Teas \& Agarwal, 2000:279; Easey, 2002:164; Frings, 2008:75). According to Roach (1994:488), a customer who is satisfied with the performance of a product will develop a degree of brand loyalty, but an unsatisfactory purchase will result in the vivid remembering of the brand name, implying that attaching a brand label to a product brings about a great accountability regarding the quality and performance of the product. 
A research finding of particular importance for this study was made by a Women's Wear Daily commission. They found that brand names are specifically significant for the casual wear category, and in the first place for jeans, followed closely by suits and dresses (Solomon \& Rabolt, 2009:397).

\subsubsection{Store image}

Store image is the overall perception the consumer has about the store's milieu and attributes (Dunne \& Lusch, 2008:433). A typical shopper may visit a store briefly and make a quick judgment of its value. As a result, that store may be placed on the consumer's list of acceptable stores, or it may be rejected and never considered again (Solomon \& Rabolt, 2009:474). Companies should aim to have a consistently good performance to keep up the image their customers prefer. Schiffman and Kanuk (2007:188) confirm that consumers rely on store image for quality, as they trust the buyers of trustworthy stores to select the products carefully, and they also expect that products will have been tested and that the store will provide good service, return privileges and correction in case of dissatisfaction.

\subsubsection{Labels}

Frings (2008:171) states that clothing labels are of huge benefit to the fashion consumers, as they provide information about the items and also serve as identification for garments. Information that may appear on clothing labels includes the name of the product, like Girl's Spencer, the trade name, like Princess, guarantees, size, performance attributes, like Light-resistant or Pre-shrunk, brand names, like Billabong or Levi, fibre content, like $60 \%$ cotton/40\% polyester, grade of quality, like Virgin wool or Pure wool, country of origin, like Made in Hong Kong, directions for use and care, like Dry flat, and care symbols (Glock \& Kunz, 1995:86; Frings, 2008:269-270).

\subsubsection{Country of origin}

Various research findings show that consumers use their knowledge of country-of-origin when making purchase decisions, especially when considering quality. Sometimes there might be a general perception that imported apparel is of higher quality, especially if the country of origin is associated with high quality fashion such as France and Italy (Schiffman \& Kanuk, 2007:458), in which case the country of origin is a significant part of the label. In other cases, the knowledge that a product is imported may lower the perception of the product quality, for instance when the import is from a third world country (Solomon \& Rabolt, 2009:399). On the other hand, consumers who are more globally orientated, especially younger ones, may not deem the country of origin important when making a purchase decision (Brown \& Rice, 2001:24).

\subsubsection{Appropriateness for casual daywear}

Several authors and researchers (Cassill \& Drake, 1987:24, Tselepis \& De Klerk, 2004:90, Frings, 2008:74) contend that it is very important that fashion consumers find suitable or acceptable fashion apparel for specific occasions or to meet the needs of their lifestyles. The female fashion consumer welcomes and enjoys the greater freedom and comfort offered by many new casual styles.

\section{Research Methodology}

The study can be described as quantitative, descriptive and exploratory in nature. The quantitative research method was chosen because it is an economical and practical way of assessing group opinions by means of a structured questionnaire which for this study was delivered by hand (Delport \& Roestenburg, 2011:188).

\subsection{Study population and sampling method}

All the female academic personnel at the seven tertiary institutions in the Vaal region were chosen as the study population. A random sampling method was applied (Strydom, 2011:226) and one hundred and fifty respondents were selected. 


\subsection{Development of the questionnaire}

A self-administered, structured questionnaire was developed to determine the importance of extrinsic evaluative criteria namely price, brand, store image, labels, country of origin and appropriateness for casual daywear when purchasing casual daywear. The respondents had to reply on a five-point Likert-type scale varying from 5 to 1 ( $5=$ very important, 4 = quite important, $3=$ not sure, 2 = of little importance, $1=$ not important at all). The questionnaire was pilot-tested for clarity and feasibility.

\subsection{Data processing and statistical analysis}

The SAS statistical package (SAS Institute Inc. 2002-2005) was used for statistical analyses of the data. The following analyses were performed: Frequency analyses for all questions; confirmatory factor analysis of the questionnaire to determine the construct validity; reliability testing by computing alpha coefficients; cluster analysis to determine whether different groups of apparel consumers could be distinguished, based on importance of evaluative criteria (Kirkwood \& Sterne, 2003:106).

\subsection{Psychometrical properties of the questionnaire}

\subsubsection{Construct validity}

This form of validity was determined by subjecting each of the subscales of the questionnaire to a factor analysis, using principle components for factor extraction. Only a few factors, which together explained a substantial proportion of the variance, were extracted for each subscale, and high communalities on each statement comprising more than half of the total variance for most of the statements were obtained, indicating satisfactory construct validity (Van Aardt \& Steyn, 1991:47).

\subsubsection{Content validity}

This could also be deemed satisfactory as all test items seemed to measure the construct which appeared as the heading of each subscale. Furthermore, all items corresponded with those in other validated measuring instruments (Hsu \& Burns, 2002:249; Retief \& De Klerk, 2003:25; North et al., 2003:44) which measured similar constructs. Also, the total set of behaviours in this section was appropriate for measuring the characteristic behaviour of the specific respondents in this study, which is another requirement for content validity (Murphy \& Davidshofer, 2005:158).

\subsubsection{Reliability}

Cronbach's alpha coefficients, which are suitable measures to indicate internal consistency of tests with multiple-scored items which are administered once, as was the case in this study, were computed. The procedure comprises the determination of the variance of all individuals' scores for each item and the addition of these variances across all items (Anastasi \& Urbina, 1997:99). The reliability coefficients for most of the factors were quite high for the overall scale. The alpha coefficients for the various factors were mostly above 0.82 . The subscales displayed satisfactory to very good reliability, except for one factor, namely price, which yielded a moderately satisfactory alpha coefficient of 0.66 . According to Malhotra and Birks (2007:358) a value of 0.6 or less indicates unsatisfactory internal consistency reliability.

In conclusion, it can be said that this section of the questionnaire, which tested quality assessment of apparel attributes, was found both valid and reliable, and could consequently be used with minor changes. All the original statements were retained.

\section{Results and Discussion}

Extrinsic attributes are a collective group of evaluative criteria that include price, brand, label, country of origin, store image and appropriateness for casual daywear. Table 1 portrays the importance of these six evaluative criteria as assessed by the respondents in this study. The positive, neutral and negative response categories were obtained in the following way: the original response categories, strongly agree and mildly agree, in the questionnaire were added together $(4+5)$ to obtain a positive response, the not sure category (3) was retained as neutral and the mildly disagree and strongly disagree original response categories were added together $(2+1)$ to obtain a negative response. 
Table 1: Importance of extrinsic apparel evaluation criteria for female casual daywear

\begin{tabular}{|c|c|c|c|c|c|c|c|}
\hline & & 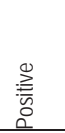 & $\begin{array}{l}\text { 쥼 } \\
\stackrel{5}{0} \\
\text { ¿ }\end{array}$ & 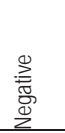 & 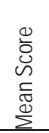 & 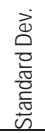 & 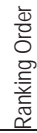 \\
\hline & \multirow[b]{3}{*}{$\mathrm{N}$} & $4+5$ & 3 & $1+2$ & & & \\
\hline & & $\mathrm{n}$ & $\mathrm{n}$ & $\mathrm{n}$ & & & \\
\hline & & $\%$ & $\%$ & $\%$ & & & \\
\hline \multicolumn{8}{|l|}{ PRICE } \\
\hline Price is an important criterion & 104 & $\begin{array}{l}78 \\
75\end{array}$ & $\begin{array}{l}9.00 \\
8.65\end{array}$ & $\begin{array}{l}17 \\
16.3\end{array}$ & 4.0 & 2.0 & 2 \\
\hline Price is a good indicator of quality & 105 & $\begin{array}{l}51 \\
48.57\end{array}$ & $\begin{array}{l}30.0 \\
28.57\end{array}$ & $\begin{array}{l}24 \\
22.9\end{array}$ & 3.4 & 1.2 & 3 \\
\hline Casual daywear must not be too expensive & 103 & $\begin{array}{l}78 \\
75.73\end{array}$ & $\begin{array}{l}15.00 \\
14.56\end{array}$ & $\begin{array}{l}10 \\
9.71\end{array}$ & 4.0 & 1.0 & 2 \\
\hline One can benefit from sales & 104 & $\begin{array}{l}79 \\
75.96\end{array}$ & $\begin{array}{l}13.00 \\
12.50\end{array}$ & $\begin{array}{l}12 \\
11.5\end{array}$ & 4.0 & 1.0 & 2 \\
\hline Casual wear should be worth the money paid & 104 & $\begin{array}{l}95 \\
91.35\end{array}$ & $\begin{array}{l}7.00 \\
6.73\end{array}$ & $\begin{array}{l}2 \\
1.92\end{array}$ & 4.5 & 0.7 & 1 \\
\hline \multicolumn{8}{|l|}{ BRAND } \\
\hline Brand is an important criterion for quality & 105 & $\begin{array}{l}35 \\
33.33\end{array}$ & $\begin{array}{l}25.00 \\
23.81\end{array}$ & $\begin{array}{l}45 \\
42.9\end{array}$ & 2.8 & 1.3 & 2 \\
\hline Brand names lend prestige & 103 & $\begin{array}{l}41 \\
39.8\end{array}$ & $\begin{array}{l}16.00 \\
15.53\end{array}$ & $\begin{array}{l}46 \\
44.7\end{array}$ & 2.9 & 1.4 & 1 \\
\hline It is a shopping time-saver & 104 & $\begin{array}{l}33 \\
31.73\end{array}$ & $\begin{array}{l}22.00 \\
21.15\end{array}$ & $\begin{array}{l}49 \\
47.1\end{array}$ & 2.7 & 1.3 & 3 \\
\hline \multirow[t]{2}{*}{ It serves as a short-cut in decision making } & 104 & $\begin{array}{l}36 \\
34.62\end{array}$ & $\begin{array}{l}29.00 \\
27.88\end{array}$ & $\begin{array}{l}39 \\
37.5\end{array}$ & 2.9 & 1.3 & 1 \\
\hline & 103 & $\begin{array}{l}36 \\
34.95\end{array}$ & $\begin{array}{l}16.00 \\
15.53\end{array}$ & $\begin{array}{l}51 \\
49.5\end{array}$ & 2.7 & 1.4 & 3 \\
\hline \multicolumn{8}{|l|}{ STORE IMAGE } \\
\hline Store name is an important criterion for casual wear & 105 & $\begin{array}{l}46 \\
43.81\end{array}$ & $\begin{array}{l}14.00 \\
13.33\end{array}$ & $\begin{array}{l}45 \\
42.86\end{array}$ & 3.0 & 1.3 & 4 \\
\hline Store name is an indicator of quality & 104 & $\begin{array}{l}64 \\
61.54\end{array}$ & $\begin{array}{l}17.00 \\
16.35\end{array}$ & $\begin{array}{l}23 \\
22.12\end{array}$ & 3.5 & 1.2 & 1 \\
\hline Buying at certain stores renders prestige & 103 & $\begin{array}{l}47 \\
45.63\end{array}$ & $\begin{array}{l}26.00 \\
25.24\end{array}$ & $\begin{array}{l}30 \\
29.13\end{array}$ & 3.2 & 1.2 & 3 \\
\hline Preference for certain stores saves time & 104 & $\begin{array}{l}54 \\
51.92\end{array}$ & $\begin{array}{l}26.00 \\
25.00\end{array}$ & $\begin{array}{l}24 \\
23.1\end{array}$ & 3.3 & 1.3 & 2 \\
\hline $\begin{array}{l}\text { LABELS } \\
\text { Information on labels is an important indication of quality }\end{array}$ & 102 & $\begin{array}{l}72 \\
70.59\end{array}$ & $\begin{array}{l}14 \\
13.73\end{array}$ & $\begin{array}{l}16 \\
15.70\end{array}$ & 3.8 & 1.1 & 4 \\
\hline $\begin{array}{l}\text { Information on labels is an important indication of quality } \\
\text { Correct care implies definite retention of shape }\end{array}$ & 104 & $\begin{array}{l}79 \\
75.96\end{array}$ & $\begin{array}{l}11 \\
10.58\end{array}$ & $\begin{array}{l}14 \\
13.50\end{array}$ & 4.0 & 1.1 & 2 \\
\hline Care instructions indicate costliness of care & 103 & $\begin{array}{l}75 \\
72.82\end{array}$ & $\begin{array}{l}15 \\
14.56\end{array}$ & $\begin{array}{l}13 \\
12.60\end{array}$ & 3.8 & 1.1 & 4 \\
\hline Fibre content is an indication of ease of care & 103 & $\begin{array}{l}59 \\
57.28\end{array}$ & $\begin{array}{l}34 \\
33.01\end{array}$ & $\begin{array}{l}10 \\
9.71\end{array}$ & 3.7 & 1.0 & 5 \\
\hline Fibre content is an indication of the durability & 103 & $\begin{array}{l}56 \\
54.37\end{array}$ & $\begin{array}{l}38 \\
36.89\end{array}$ & $\begin{array}{l}9 \\
8.74\end{array}$ & 3.6 & 1.0 & 6 \\
\hline Fibre content is an indication of the comfort & 104 & $\begin{array}{l}62 \\
59.62\end{array}$ & $\begin{array}{l}34 \\
32.69\end{array}$ & $\begin{array}{l}8 \\
7.69\end{array}$ & 3.7 & 1.0 & 5 \\
\hline Fibre content can be an indication of garment cost & 104 & $\begin{array}{l}56 \\
53.85\end{array}$ & $\begin{array}{l}35 \\
33.65\end{array}$ & $\begin{array}{l}13 \\
12.5\end{array}$ & 3.6 & 1.0 & 6 \\
\hline Fibre content is related to appearance & 103 & $\begin{array}{l}62 \\
60.19\end{array}$ & $\begin{array}{l}29 \\
28.16\end{array}$ & $\begin{array}{l}12 \\
11.7\end{array}$ & 3.7 & 1.0 & 5 \\
\hline It is important to know your size & 104 & $\begin{array}{l}75 \\
72.12\end{array}$ & $\begin{array}{l}19 \\
18.27\end{array}$ & $\begin{array}{l}10 \\
9.62\end{array}$ & 3.9 & 1.1 & 3 \\
\hline Correct size is important for consumer satisfaction & 97 & $\begin{array}{l}90 \\
92.78\end{array}$ & $\begin{array}{l}2 \\
2.06\end{array}$ & $\begin{array}{l}5 \\
5.15\end{array}$ & 4.5 & 0.8 & 1 \\
\hline COUNTRY OF ORIGIN & & & & & & & \\
\hline Country of origin is an important criterion for casual wear & 105 & $\begin{array}{l}29 \\
27.62\end{array}$ & $\begin{array}{l}26.00 \\
24.76\end{array}$ & $\begin{array}{l}50 \\
47.6\end{array}$ & 2.6 & 1.2 & 2 \\
\hline Country of origin is an indication of quality & 104 & $\begin{array}{l}40 \\
38.46\end{array}$ & $\begin{array}{l}29.00 \\
27.88\end{array}$ & $\begin{array}{l}35 \\
33.7\end{array}$ & 2.9 & 1.2 & 1 \\
\hline One should try to detect the country of origin & 104 & $\begin{array}{l}26 \\
25\end{array}$ & $\begin{array}{l}23.00 \\
22.12\end{array}$ & $\begin{array}{l}55 \\
52.9\end{array}$ & 2.5 & 1.2 & 3 \\
\hline APPROPRIATENESS FOR CASUAL DAYWEAR & & & & & & & \\
\hline Appropriateness of style / design is important & 105 & $\begin{array}{l}88 \\
83.81\end{array}$ & $\begin{array}{l}13.00 \\
12.38\end{array}$ & $\begin{array}{l}4 \\
3.81\end{array}$ & 4.2 & 0.8 & 3 \\
\hline Style / design should be comfortable & 104 & $\begin{array}{l}95 \\
91.35\end{array}$ & $\begin{array}{l}8.00 \\
7.69\end{array}$ & $\begin{array}{l}1 \\
0.96\end{array}$ & 4.5 & 0.7 & 1 \\
\hline Appearance of garment must be compatible with idea of casual wear & 103 & $\begin{array}{l}93 \\
90.29\end{array}$ & $\begin{array}{l}8.00 \\
7.77\end{array}$ & $\begin{array}{l}2 \\
1.94\end{array}$ & 4.4 & 0.7 & 2 \\
\hline
\end{tabular}




\subsection{Price}

Regarding price it is clear that the majority of the respondents $(91.35 \%)$ strongly or mildly agreed with one of the statements regarding price, namely that casual daywear should be worth the money paid for it, with a mean score rating of 4.5. However, just less than half of the respondents positively agreed that price is a good indicator of quality, while $30 \%$ were not sure of this. In general, it seems that they found price an important criterion to assess value for money, but not to assess clothing quality.

Brijball $(2003: 94,95)$ found that the consumer makes use of price as an indicator of quality when the decisionmaking is hazardous, but when the consumer is familiar with the product, price is not vital. Zhang et al. (2002:56) also found that price is a less important attribute when evaluating casual wear. Ahmed and D'Astous (2004:196) as well as Verma and Gupta (2004:75) found that price influences consumers' perception of quality. In a comparative study between Chinese and Indian consumers' evaluative criteria when selecting denim jeans it was found that only about a fifth of Indian consumers (19.62\%) deemed price an important selection criterion while slightly more (27.26\%) Chinese consumers found price an important criterion (Jin, Park \& Ryu, 2010:180).

\subsection{Brand}

Concerning brand, the relatively low mean scores (2.7-2.9) obtained for all five statements regarding brand indicated that these consumers did not consider brand very important when evaluating clothing quality. Only about a third agreed that they would benefit from buying brand names, while nearly half of the respondents (46.0-49.5\%) strongly or mildly disagreed with the statements that claim that brand names are important when evaluating clothing quality, that they lend prestige, that a brand name is a shopping time-saver and that it can be used as a short-cut in decision making.

D'Astous and Saint-Louis (2005:307) found that if garments are to be worn every day (like casual wear) brand name may have less importance than if garments are purchased for special occasions. In a South African study by Van Eck et al. (2004:11) it was found that black adolescent males and females perceive branded clothing more positively than unbranded clothing. In another South African study by Herbst and Burger (2002:43), brand, with an importance of 32.2 percent, was found to be the most important attribute used by youngsters between 13 and 16 years of age for assessing fashion products. Taylor (2003:7) contends that brand is not any longer a short-lived image wrapper or a managerial blueprint for value creation, as research indicates that brands tend to promise more than they deliver. A research finding of particular importance for this study was made by a Women's Wear Daily commission. They found that brand names are specifically significant for the casual wear category, and in the first place for jeans, followed closely by suits and dresses (Solomon and Rabolt, 2009:397). According to Roach (1994:488), a customer who is satisfied with the performance of a product will develop a degree of brand loyalty, but an unsatisfactory purchase will result in the vivid remembering of the brand name, implying that attaching a brand label to a product brings about a great accountability regarding the quality and performance of the product.

\subsection{Store image}

The respondents were not very positive regarding the value of store name when making decisions about the quality of apparel, with mean score ratings between 3.0 and 3.5. Less than two-thirds were of the opinion that a store name is an indicator of apparel quality, with a mean score rating of 3.5, as 61.54 percent of these consumers were strongly or mildly in agreement with the statement. Only 43.81 percent strongly or mildly agreed that the store name is an important criterion when buying casual wear.

Research findings on the influence of store image on consumers' perceptions of quality are inconsistent. Some studies found that customers perceived the quality of specific apparel products lower when coming from a low-prestige store, than when they were told that the product was from a high-prestige store. It was also found that store prestige was inversely related to perceived risk. Other studies found that the effect of store image on perceived quality of products was small and statistically insignificant (Griffin \& O'Neal, 1992:176), and even less important in case of everyday wear (D'Astous and Saint-Louis, 2005:307)

\subsection{Labels}

Results show that these consumers were slightly more positive about labels than about store names as an important criterion when purchasing casual wear, with mean score ratings varying between 3.6 and 4.5 . The size indication on the 
label seemed to be most important to them, with a mean score rating of 4.5 and 92.7 percent strongly or mildly in agreement with this statement, while the care instructions seemed fairly important, as 75.96 percent strongly or mildly agreed that following care instructions on labels would warrant retention of the garment's shape and appearance and $72.8 \%$ agreed that this information could help them to determine the costliness of the care procedures. Fibre content seemed to be of moderate importance when evaluating garment quality, with mean score ratings varying between 3.6 and 3.7 .

Niemann (2010:119) concluded that consumers do use labels, depending on the usefulness of the information, before, during and after purchasing of clothing products. She recommends that marketers and consumer educators take action to inform consumers about the meaning of information on clothing labels and to emphasize the importance of using clothing labels during apparel purchasing decisions.

\subsection{Country of origin}

From the importance attached to country of origin as a measure of apparel quality it can be detected that the respondents were not convinced that the country of origin of garments was an important criterion when buying casual wear. More than half (52.9 percent) were negative about the necessity of making an effort to detect the country where the garment was made, and 61.6 percent were negative or neutral as to whether the country of origin is an indication of garment quality. The mean score rating for all the statements with regard to country of origin varied between 2.5 and 2.9 , confirming that the respondents did not esteem this an important quality assessment criterion when buying casual wear.

Chen-Yu and Kincade (2001:38) as well as Khachaturian and Morganosky (1990:21) report several research studies which found a significant relationship between country of origin and assessment of apparel quality. Consumer who are more globally orientated, especially younger ones, may not deem the country of origin important when making a purchase decision (Brown \& Rice 2001:24). Ahmed and D'Astous (2004:193) found that, in addition to age, demographic variables such as income and education were also strongly related to the evaluation of apparel products in terms of the country of origin. Hawkins et al. (2007:305) confirm that consumers may interpret the quality of products more positively when manufactured in a country that they perceive positively in terms of product image. Fashion product image is often influenced by its country of origin, which in turn contributes to determination of its "brand personality" (Solomon \& Rabolt, 2009:5).

\subsection{Appropriateness for the purpose}

Regarding opinion of the importance of the appropriateness of outfits for a specific purpose (in this case casual daywear) as quality assessment criterion, it is clear that these respondents found it quite important that outfits bought for casual daywear should be appropriate for the purpose. As many as 91.3 percent strongly or mildly agreed that the style/design of casual daywear should be comfortable, with a mean score rating of 4.5 , while 90.29 percent strongly or mildly agreed that the appearance of the outfit should be compatible with the idea of casual daywear, with a mean score rating of 4.4.

Frings (2008:74) argues that clothing consumers should take into account their apparel needs for work and leisuretime activities. Appropriateness also entails the suitability and comfort of the style, fabric, freedom of movement, durability, ease of care and attractiveness in relation to the purpose of the garment. In a cross-national comparative study, Hsu and Burns (2002:251) found that Taiwanese students placed more emphasis on appropriateness of clothing for campus wear than did their United States counterparts. Fiore and Damhorst (1992:174) found that aesthetic attributes were related to situational appropriateness, while consumers in a study by Abraham-Murali and Littrell (1995b:71) related the appropriateness of a garment to lifestyle.

\subsection{Cluster analysis}

Cluster analysis is a statistical technique which investigates a collection of variables to determine whether individuals can be clustered into a natural system of groups (Kirkwood \& Sterne, 2003:106). The StatSoft Inc. (2006) STATISTICA data analysis software system was used to cluster the respondents in this study with regard to the evaluative criteria. The results are graphically displayed in figure 2 , with the mean cluster scores given on the $X$-axis and the evaluative criteria on the Y-axis. The mean cluster scores for the six extrinsic apparel evaluative criteria revealed that three clusters could be distinguished, each with a specific disposition towards the evaluative criteria listed in the questionnaire. The clusters were named unconcerned shoppers (cluster $1, n=10$ ), non status-conscious, sensible shoppers (cluster 2, $\mathrm{n}=42$ ) and intensive evaluating shoppers (cluster $3, n=52$ ). 


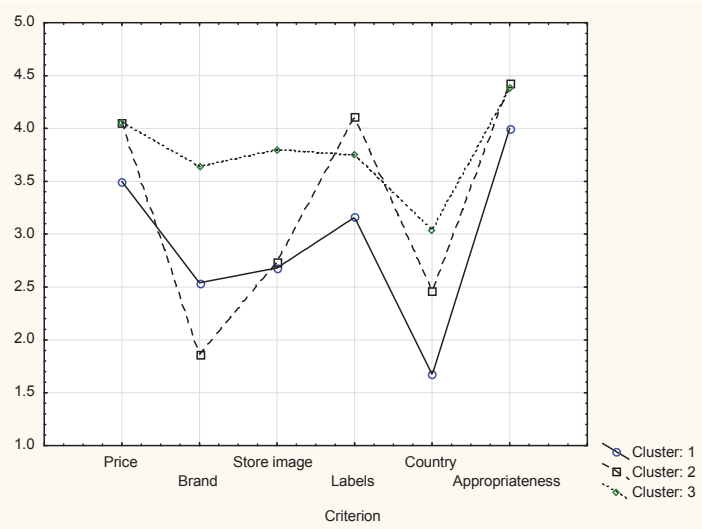

Figure 2: Cluster analysis for extrinsic apparel evaluative criteria factors

\subsubsection{Cluster 1: Unconcerned shoppers}

The female consumers in this smallest cluster $(n=10)$ evaluated all of the extrinsic attributes except brand, lower than the other two groups, which is an indication that they were not as concerned about these evaluative criteria as the other groups. Appropriateness of garments for the purpose, in this case casual daywear, was their biggest concern, followed by price.

\subsubsection{Cluster 2: Non status-conscious, sensible shoppers}

This cluster did not regard extrinsic attributes such as brand very important (mean score $<2.0$ ) nor were country of origin and store image important to them when evaluating clothing quality, highlighting the fact that for them, practicality was an important factor in choosing casual daywear. Consequently, appropriateness of garments for the purpose, followed by price and labels (probably because of the useful information on them), were of greatest importance to them.

\subsubsection{Cluster 3: Intensive evaluating shoppers}

This biggest cluster ( $\mathrm{n}=52$ ) showed that four extrinsic criteria (price, brand, store image and labels) were of fairly high importance to them, while they were most concerned about the appropriateness of the garments for the purpose.

To summarise, the clustering results reveal that three groups of respondents, which differed in their use of evaluative criteria, could be distinguished, implying that these respondents could be divided into three market segments with different interests when shopping for casual daywear.

\section{Conclusion}

Apparel consumers differ with regard to the importance of the various extrinsic criteria which they apply when evaluating clothing quality with regard to casual daywear.

\subsection{Importance of the various extrinsic evaluative criteria}

Regarding the application of extrinsic evaluative criteria for quality assessment, when looking at the mean scores in Table 1, appropriateness of the garments for a specific purpose, in this case casual daywear, was rated most important, possibly due to the fact that these respondents were lecturers and maybe were of the opinion that they should set an example for the students and command respect, followed by price and labels, which perhaps can be explained by the fact that these academics are rational and reason cognitively about their quality judgments. Store image was in the fourth place for the overall group of respondents and only of moderate importance to half of these respondents, while for the other half, identified as intensive evaluating shoppers, store name and image was highly important. Brand and country of origin were rated much lower than all the other attributes, which could be attributed to a low need for status among these 
academics, probably since their career as lecturers at a tertiary institution already bears testimony of high status.

\subsection{Recommendations and implications for clothing manufacturers and retailers.}

Apparel manufacturers and retailers should take note of the outcomes of studies like this one in order to understand consumers' selection criteria when purchasing apparel. efficiently.

In-depth information on apparel consumer preferences could help retailers to plan their merchandise mix more

When planning methods of conveying marketing messages as well as the contents of these messages during promotional activities, information on apparel consumers' use of evaluative criteria should be considered, such as: "We have the right outfit for every occasion" or "Best prices for clothing found here".

Retailers should guide and prepare their sales personnel to address and highlight the apparel attributes of importance to various consumer groups when giving sales assistance, such as to ask the customers for what occasion they need a specific garment, and then make them aware of the importance of the various evaluative criteria for that specific purpose.

Information on preferences of different apparel consumer groups could be used by marketers and retailers to identify niche markets and to develop targeting strategies and an applicable market mix for the various niche markets.

Retailers could, in co-operation with consumer educational authorities, develop educational opportunities during which consumers could be made aware of the importance of using a wide variety of applicable evaluative criteria in order to make informed and responsible apparel purchase decisions.

\subsection{Concluding remarks}

Trends in the fashion market are changing rapidly and marketers are not always aware of contemporary needs of different consumer groups. Changes in social patterns and lifestyle are reflected in clothing. Higher educational levels, better transport which increases mobility, the changing role of women who are increasingly filling career positions and changing value systems, lead to changes in fashion trends, consumer needs and ways in which apparel is evaluated. More leisure time as a result of workers' demand for shorter working hours and a culture of going on holiday more frequently have created a need for casual clothing. The understanding of preferences and needs with regard to casual wear and of the criteria used for assessing the quality of casual wear is consequently a very relevant concern which has been addressed in this study and which should receive more attention in future research.

\section{References}

Abraham-Murali, L., \& Littrell, M. A. (1995a). Consumers' perceptions of apparel quality over time: An exploratory study. Clothing and Textiles Research Journal, 13(3), 149-158.

Abraham-Murali, L., \& Littrell, M. A. (1995b). Consumers' conceptualisation of apparel attributes: An exploratory study. Clothing and Textiles Research Journal, 13(2), 65-74.

Ahmed, S. A., \& D'Astous, A. (2004). Perceptions of countries as producers of consumer goods. Journal of Fashion Marketing and Management, 8(2), 187-200.

Anastasi, A., \& Urbina, S. (1997). Psychological testing (7th ed.). Upper Saddle River, NJ: Prentice Hall.

Baron, R. A., \& Byrne, D. (2000). Social psychology (9th ed.). London: Allyn and Bacon.

Brijball, S. (2003). The level of importance attached to price and quality in purchasing behaviour. SA Journal of Industrial Psychology, 29(1), 93-99.

Brown, P., \& Rice, J. (2001). Ready-to-wear apparel analysis (2nd ed.). Upper Saddle River, NJ: Prentice Hall.

Cassill, N. L., \& Drake, M. F. (1987). Apparel selection criteria related to female consumers' lifestyle. Clothing and Textiles Research Journal, 6(1), 20-28, Fall.

Chen-Yu, H. J. \& Kincade, D. H. (2001). Effects of product image at three stages of the consumer decision process for apparel products: Alternative evaluation, purchase and post-purchase. Journal of Fashion Marketing and Management, 5(1), 29-43.

D'Astous, A. \& Saint-Louis, O. (2005). National versus store brand effects on consumer evaluation of a garment. Journal of Fashion Marketing and Management, 9(3), 306-317.

Delport, C. S. L., \& Roestenburg, W. J. H. (2011). Quantitative data-collection methods: Questionnaires, checklists, structured observation and structured interview schedules. In A. S. de Vos, H. Strydom, C. B. Fouché \& C. S. L. Delport (Eds.), Research at grass roots: For the social sciences and human service professions (4th ed.)(pp.171-205). Pretoria: Van Schaik.

Dunne, P. M., \& Lusch, R. F. (2008). Retailing (6th ed.). Mason, OH: Thomson South-Western.

Easey, M. (2002). Fashion marketing (2nd ed.). Oxford: Blackwell. 
Eckman, M., Damhorst, M. L., \& Kadolph, S.J. (1990). Toward a model of the in-store purchase decision process: Consumer use of criteria for evaluating women's apparel. Clothing and Textiles Research Journal, 8(2), 13-22, Winter.

Erasmus, A. C., Boshoff, E., \& Rousseau, G. G. (2002). The potential of using script theory in consumer behaviour research. Journal of Family Ecology and Consumer Sciences, 30, 1-9.

Fiore, A. M., \& Damhorst, M. L. (1992). Intrinsic cues as predictors of perceived quality of apparel. Journal of Consumer Satisfaction, Dissatisfaction and Complaining Behaviour, 5, 168-178.

Forsythe, S., Presley, A. B., \& Caton, K. W. (1996). Dimensions of apparel quality influencing consumers' perception. Perceptual and Motor Skills, 83, 299-305.

Frings, G. S. (2008). Fashion from concept to consumer (9th ed.). Upper Saddle River, NJ: Prentice Hall.

Glock, R. E., \& Kunz, G. I. (1995). Apparel manufacturing (2nd ed.). Engelwood Cliffs, NJ: Prentice Hall.

Griffin, M. L., \& O'Neal, G. S. (1992). Critical characteristics of fabric quality. Home Economics Research Journal, 21(2), 173-191, Dec.

Hawkins, D. I., Mothersbaugh, D. L., \& Best, J. R. (2007). Consumer behavior: Building marketing strategy (10th ed.). New York, NY: McGraw-Hill Irwin

Herbst, F., \& Burger, C. (2002). Attributes used by young consumers when assessing a fashion product: A conjoint analysis approach. Journal of Family Ecology and Consumer Sciences, 30, 40-45.

Hines, J. D., \& O'Neal, G.S. (1995). Underlying determinants of clothing quality: The consumers' perspective. Clothing and Textiles Research Journal, 13(4), 227-233.

Hoyer, W. D., \& MC Innes, D. J. (2007). Consumer behaviour (4th ed.). Boston, Mass: Houghton Mifflin.

Hsu, H-J., \& Burns, L. D. (2002). Clothing evaluative criteria: A cross-national comparison of Taiwanese and United States consumers. Clothing and Textiles Research Journal, 20(4), 246-252.

Hugo, S. H., \& Van Aardt, A. M. (2012). Evaluative criteria applied by South African female fashion consumers when purchasing casual daywear. International Journal of Consumer Studies, 36, 460-471.

Jin, B., Park, J. Y., \& Ryu, J. S. (2010). Comparison of Chinese and Indian consumers' evaluative criteria when selecting denim jeans: A conjoint analysis. Journal of Fashion Marketing and Management, 14(1), 180-194.

Kadolph, S. J. (1998). Quality assurance for textiles and apparel. New York, NY: Fairchild.

Khachaturian, J. L., \& Morganosky, M.A. (1990). Quality perceptions by country of origin. International Journal of Retail and Distribution Management, 18(3), 21-30.

Kirkwood, B. R., \& Sterne, J. A. C. (2003). Essential medical statistics (2nd ed.). Malden, Mass.: Blackwell.

Kotler, P., \& Armstrong, G. (2010). Principles of marketing. (13th ed.). New York, NY: Pearson

Malhotra, N. K., \& Birks, D. F. (2007) Marketing research: An applied approach. (3rd ed.). New York. NY: Prentice Hall.

Murphy, K. R., \& Davidshofer, C.O. (2005). Psychological testing: Principles and applications (6th ed.). Upper Saddle River, NJ: Prentice Hall.

North, E. J., De Vos, R. B., \& Kotzé, T. (2003). The importance of apparel product attributes for female buyers. Journal of Family Ecology and Consumer Science, 31, 41-51.

Niemann, A. M., (2010). Male and female consumers' knowledge, perceptions and use of clothing labels (unpublished master's thesis). North-West University, Potchefstroom.

Retief, A., \& De Klerk, H. M. (2003). Development of a guide for the visual assessment of the quality of clothing textile products. Journal of Family Ecology and Consumer Science, 31, 21-29.

Roach, A. R. (1994). Meeting consumer needs for textiles and clothing. Journal of the Textile Institute, 85(4), 484-495.

Rosenau, J. A., \& Wilson, D.L. (2006). Apparel merchandising: The line starts here (2nd ed.). New York, NY: Fairchild.

SAS Institute Inc. (2005). SAS Online Doc ® Version 9.1 (4th ed.). Cary, NC: SAS Institute, Inc.

Schiffman, L. G., \& Kanuk, L. L. (2007). Consumer behaviour (9th ed.). Upper Saddle River, NJ: Prentice Hall.

Solomon, M. R., \& Rabolt, N. J. (2009). Consumer behaviour in fashion. Upper Saddle River, NJ: Prentice Hall.

STATSOFT Inc. (2006) STATISTICA (data analysis software system), version 7.1 Retrieved from http://www.statsoft.com

Strydom, H. (2011) Ethical aspects of research in the social sciences and human service professions. In A. S. de Vos, H. Strydom, C. B. Fouché, \& C. S. L. Delport (Eds.) Research at grass roots: For the social sciences and human service professions. (5th ed.) (pp. 113-130). Pretoria: Van Schaik.

Taylor, D. (2003). The brandgym: A practical workout for boosting brand and business. Chichester, UK: Wiley.

Teas, R. K., \& Agarwal, S. (2000). The effects of extrinsic product cues on consumers' perceptions of quality, sacrifice, and value. Journal of the Academy of Marketing Science, 28(2), 278-290.

Tselepis, T., \& De Klerk, H. M. (2004). Early adolescent girls' expectations about the fit of clothes: A conceptual framework. Journal of Family Ecology and Consumer Science, 32, 83-93.

Van Aardt, A .M., \& Steyn, H. S. (1991). Die konstruksie van 'n houdingskaal vir tekstiele. Journal of Dietetics and Home Economics, 19(2), 43-48.

Van Eck, A., Grobler, A. F., \& Herbst, F.J. (2004). Perceptions of branding in the clothing industry: A survey among black adolescents. Communicare, 23(1), 1-14, Jul.

Verma, D. P. S., \& Gupta, S. S. (2004). Does higher prices signal better quality? Vikalpa, 29(2), 67-77.

Zhang, Z., Li, Y., Gong., C., \& Wu, H. (2002). Casual wear product attributes. Journal of Fashion Marketing and Management, 6(1), 5362. 